have seen. Passing from without inwards, he describes-1st. A " Couche albide superficiale." This, I presume, corresponds with all that part of the epidermoid tissue which is placed exterior to the epidermoid glands. 2nd. "Les Gemmules." These are, I also presume, the epidermoid glands, which form almost a membrane, or continuous stra. tum, so closely are they placed to each other. 3d. A " Couche albide profonde." This appears to be so much of the epidermoid tissue, or of the rete, as is placed under" the epidermoid glands. 4th. "Les bourgeons sanguines." These are, most probably, the eminences occasionally formed by the points of the cutis, which correspond to the epidermoid glands, or upon which these glands are placed. And, 5thly, the "derme," which is the cutis. Thus, you observe, that so far there is no irreconcileable difference between our observations and the descriptions of Gaultier. Not so, however, when we look at the plates which represent his views. We there observe that he delineates the "Bourgeons sanguines," bifid. But if the eminences which he denominates "Bourgeons sanguines" are bifid, they cannot be seated on the part of the cutis upon which the epidermoid glands are placed, for the papilliform eminences sometimes developed on these points are never, so far as $I$ have observed, bifid.

How is the difference between Gaultier's plates, and what we have observed, to be explained? Thus, it appears to me, that he has taken his figures of the "Bourgeons sanguines," from the papillæ on the hands, which, in this situation, pass up between the epidermoid glands, and are, for the reasons already mentioned, bifid; while he has taken his representations of the "gemmules" from the general surface. But, it may be asked, why did he do so? I answer, because the largest gemmules are on the general surface, and because of the size of the papilliform eminences on the hands and feet, which eminences he mistook for those occasionally developed under the epidermoid glands. He has hence delineated epidermoid glands on villi, and has thereby fallen into a striking error.

I shall not attempt so vain a task as to reconcile the account of the structure of the skin which Breschet has given, with the facts we have seen. It would be impossible, yet $I$ cannot help observing, that were $I$ to draw an ideal representation of the cutaneous organ from my knowledge of its functions, I should be very likely to produce a picture far from unlike that which has been furnished to us by Breschet and Roussel de Vauzeme.

\section{DESCENT OF INTESTINE THROUGH THE ANUS.}

To the Editor of The LANcet.

SiR:-I beg to send you the following account of a case which recently came under my notice, and which I consider to be very extraordinary in its nature. I am, Sir, your obedient servant,

George P. MaY, M,D., M,R.C,S,E, Maldon, Nov, 19, 1837.

On the 14th of September last, I received a message requesting my immediate attendance upon Mrs. S—. On my arrival I was told by the atteudants that "her inside had come out;" knowing, however, that she had formerly some disposition to prolapsus ani, I concluded that the accident was merely an eversion of a portion of the rec. tum. On removing the bed-clothes I was astonished to see three or four folds of in. testine protruding from the anus, and lying in the bed. On examination $I$ found the mucous membrane at the termination of the rectum everted to the extent of an inch, forming a ring through which nearly two feet of the small intestine had passed, the peritoneal surface of which exhibited marks of high vascularity. After much difficulty, owing to the obstinacy of the patient, and her determined opposition to my efforts, I succeeded in returning the gut. In about six hours it descended again, to a greater extent than before ; I could now distinctly perceive the visceral attachment of the mesentery. The bowel exhibited a dark chocolate colour, precisely similar to that which is so frequently observed in strangulated hernia. I again returned the intestine, and confined it by a bandage and compress applied to the anus. Symptoms of peritoneal inflammation supervened in a few hours, and proceeded to a fatal inflammation on the fifth day after the accident. I much regret to state that $I$ was unable to make a post-mortem examination of the body, but it appears pretty certain that there must have been a rupture through the coats of the colon, or the upper part of the rectum, through which the small intestine passed.

It is proper to observe that the patient had for three years been the subject of hemiplegia, and her intellectual faculties were much impaired, to which circumstance may be attributed her utter carelessness as to her condition, which was discovered by her friends, quite in an accidental manner. 